\begin{tabular}{cc}
\hline International Journal of Engineering \& Technology, $7(3.21)(2018) 5-9$ \\
International Journal of Engineering \& Technology \\
Website: $w$ ww.sciencepubco.com/index.php/IJET \\
Research paper
\end{tabular}

\title{
Capital Budgeting Model and Sensitivity Analysis of the Conventional Oil Production Sharing Contract (PSC) Fiscal Systems: Empirical Evidence from Indonesia
}

\author{
Wiwiek Mardawiyah Daryanto ${ }^{1}$, Arti Primadona ${ }^{2}$ \\ ${ }^{1}$ Sekolah Tinggi Manajemen Ipmi, Jakarta 12750, Indonesia \\ ${ }^{2}$ Institut Teknologi Bandung, Bandung 40132, Indonesia \\ *Corresponding author E-mail: wiwiek.daryanto@ipmi.ac.id
}

\begin{abstract}
Oil is a vital commodity that controls the livelihood of people. It is also the main resource of state revenue. The oil industry in Indonesia has started since 1883 . However, only 40 percent of the total sedimentary basin in Indonesia has been explored since that time (Ministry of Energy and Mineral Resources of Republic of Indonesia, 2015). Accordingly, the major fields are getting drain, while the domestic consumption of oil is increasing. Low investment is one of the factors that cause the declines of oil production. Working Areas (WA) which had been offered to the potential investors by the Government of Indonesia (GOI) during the period ended September 10, 2015, were unsold, followed by unsuccessful of seven WAs offered in the period from July 18 to October 28, 2016, due to an unattractive terms and conditions of PSC Fiscal Systems in the decreasing of oil price situation currently. Oil business requires high capital, high technology, high risks, long terms commitment, but high returns. Therefore, GOI always depends on the private investor to run exploration and exploitation of oil mining. The purpose of this study is to measure the feasibility of oil industry investment and to examine the attractive terms and conditions of PSC Fiscal Systems. The data were collected from the ten PSC Fiscal Systems which had been started the business since 1968 - 2014. Capital Budgeting Model indicators: Payback Period, Net Present Value (NPV), Internal Rate of Return (IRR), and Weighted Average Cost of Capital (WACC) were used to analyze the data and sensitivity analysis. The finding shows that the attractive terms and conditions of PSC Fiscal Systems are a maximum split of 50 percent for GOI, under controllable Cost Recovery (CR), the oil price of USD 50.00/barrel, and WACC $<20 \%$. The authors believe that the findings will be beneficial for GOI and potential oil investors to carry out a fair negotiation, to come up with a win-win solution.
\end{abstract}

Keywords: PSC; cost recovery; capital budgeting model; net present value; internal rate of returns.

\section{Introduction}

Indonesia's economy has experienced steady growth emerging from the Asian financial crisis of 1997-1999, averaging stable 5 $6 \%$ annual growth rate, and the strength of the country's economy was formerly based on its considerable oil exports (1). There are many countries that depend on the income of oil exports such as Iraq, Kuwait, Saudi Arabia, Libya, Angola, Oman, Brunei, Kazakhstan, Russian, and much more (2). As a country with a continuity growing economy, a critical component of Indonesia's future strength will be its ability to harness and manage sustainable sources of energy. The primary body responsible for governing the Indonesia's energy is the Ministry of Energy and Minerals Resources (MEMR). The MEMR in year 2015 estimates that domestic demand for energy will rise by around $7 \%$ per year, with electricity demand alone projected to nearly triple between 2010 and 2030. According to National Energy Council in year 2016, electricity consumption/capita was estimated to $2,500 \mathrm{KWh}$ in 2025 , and increase to 7,000 in 2050 .

Based on the Decree of the MEMR no. 35, 2008, the objective of a host government (GOI) is to maximize wealth from its natural resources by encouraging appropriate levels of exploration and development activities. Therefore, GOI should design PSC fiscal systems that: provide a return to the state and to the industry; avoid undue speculation; limit undue administrative burden; provide flexibility, create healthy competition and market efficiency. Unfortunately, there were 7 WAs offered for regular bidding during the period of July 18 to October 28, 2016, but none of the investor interested in the bidding MEMR in year 2016. Stronger incentives in PSC and fiscal terms may be needed for them to undertake the projects. The 7 WAs are: 1) South CPP (On-shore Riau); 2) Oti (Offshore East Kalimantan); 3) Suremana (Makassar Strait); 4) Manakarra Mamuju (Makassar Strait); 5) South East Mandar (Off-shore South Sulawesi); 6) North Aguni (On-shore West Papua); and 7) Kasuri II (On-shore West Papua) (MEMR, 2016). According to Anthony, Hawkins, \& Merchant (3), Capital Investment Problems, also commonly called Capital Budgeting Problems is defined as alternative decisions to those that involve relatively long-term differential investments of capital. A capital budget is a list of the capital investment projects that an organization has decided to carry out. The long-term investment aspect of capital budgeting problems leads to a more complicated analytical approach. It is important that these complications be mastered because capital budgeting decisions do lock in the organization to a course of action for several, perhaps many, future years. Five elements involved in capital investment calculations:1) Required rate of return; 2) Economic life (number of years for which cash 
inflows are anticipated); 3) Amount of cash inflow in each year; 4) Amount of investment, and 5) Terminal value.

This study is focusing on the oil industry, covering 10 oil fields under PSC Fiscal System which have been operating in Indonesia since the period of $1968-2014$. The purpose of this study is to measure the feasibility of oil industry investment and to examine the attractive terms and conditions of PSC Fiscal Systems using capital budgeting model. The findings of the study will be beneficial for GOI and potential oil investors to carry out a fair negotiation, to come up with the win-win solution. The outcome of this study will also facilitate the students and academicians to assess the correlation of PSC Fiscal Systems and Capital Budgeting Model in order that the learning will be more practical and understood to be used in the decision-making process. This study is organized into seven sections. Section one captures the introduction, section two highlight the development of oil in Indonesia, section three highlight the PSC Fiscal Systems in Indonesia, section four highlight the literature review about previous researchers, section five discuss the methodology, section six discuss the finding and analysis, section seven highlights the implication and section seven captures the conclusion.

\section{Literature Review}

\subsection{Development of Oil Industry in Indonesia}

According to MEMR in year 2015, 40\% of the total basins in Indonesia have been explored and located in Western Indonesia, and the remaining $60 \%$ have not been explored and located in Eastern Indonesia. Those oil fields have been producing since the last decade, and it is getting drain due to over mature of the oil field. This condition should be balanced by increasing reserve replacement ratio. However, the ratios decreased from $52.2 \%$ in 2012 to $44.42 \%$ in 2013 due to lack of exploration and low discoveries. Based on Table 1, the number of the new contract signed decreased significantly from 28 WAs in 2007 to 12 WAs in 2015; and the highest number was 39 WAs in 2012. In the case of oil production, the Table 1 also shows that the number of crude oil production decreased by 972 thousand barrels of oil equivalents per day in 2007 to 779 thousand barrels of oil equivalents per day in 2015 , while the number of natural oil production increased from 7,238 thousand barrels of oil equivalents per day in 2007 to 8,102 thousand barrels of oil equivalents per day in 2015 .

Table 1: Key Indicator

\begin{tabular}{|c|c|c|c|c|c|c|c|c|c|}
\hline \multirow{2}{*}{$\begin{array}{c}\text { Indicator } \\
\text { Reserves }\end{array}$} & 2007 & 2008 & 2009 & 2010 & 2011 & 2012 & 2013 & 2014 & 2015 \\
\hline & & & & & & & & & \\
\hline $\begin{array}{l}\text { Reserves } \\
\text { Oil (Million } \\
\text { Barrels) }\end{array}$ & 8,400 & 8,220 & 8,000 & 7,760 & 7,730 & 7,410 & 7,550 & 7,370 & $7,370^{*}$ \\
\hline Proven & 3,990 & 3,750 & 4,300 & 4,230 & 4,040 & 3,740 & 3,690 & 3,620 & 3,692 \\
\hline \multirow{2}{*}{$\begin{array}{l}\text { Potential } \\
* * \text { Gas (TCF) }\end{array}$} & 4,410 & 4,470 & 3,700 & 3,530 & 3,690 & 3,670 & 3,860 & 3,750 & $3,750^{*}$ \\
\hline & 165.00 & 170.10 & 159.63 & 157.14 & 152.89 & 150.70 & 150.39 & 149.30 & $149.30^{*}$ \\
\hline Proven & 106.00 & 112.50 & 107.34 & 108.40 & 104.71 & 103.35 & 101.54 & 100.26 & 103.35 \\
\hline \multirow{2}{*}{$\begin{array}{l}\text { Potential } \\
\text { Production }\end{array}$} & 59.00 & 57.60 & 52.29 & 48.74 & 48.18 & 47.35 & 48.85 & 49.04 & 49.04* \\
\hline & & & & & & & & & \\
\hline $\begin{array}{ll}*{ }^{* * *} \text { Crude } & \text { Oil } \\
\text { (MBOPD) } & \end{array}$ & 972 & 1,006 & 994 & 1,003 & 952 & 918 & 825 & 789 & 779 \\
\hline $\begin{array}{l}\text { *** Natural gas } \\
\text { (MMSCFD) }\end{array}$ & 7,283 & 7,460 & 7,962 & 8,857 & 8,415 & 7,110 & 6,826 & 8,218 & 8,102 \\
\hline $\begin{array}{l}\text { New contract } \\
\text { signed }\end{array}$ & 28 & 34 & 34 & 21 & 31 & 39 & 14 & 7 & 12 \\
\hline $\begin{array}{l}\text { Source: } \\
* 2007-2014 \\
* 2015 \text { Oil p } \\
* * 2007-201 \\
* * 2015 \mathrm{Ga} \\
\text { available } \\
{ }^{* * *} 2007-2 \\
2014 \text { Crude } \\
{ }^{* * *} 2015 \mathrm{C} \\
* * * 2015 \mathrm{C}\end{array}$ & te oil $\mathrm{p}$ & suctor & KK Migas & $\mathrm{SD}$ & aget & tion) & 14 & data & \\
\hline
\end{tabular}

In terms of oil price, the industry experienced significant volatility in the global market (4-7) supported that the oil price has been volatile since its first oil crisis in 1973. Based on PWC report in year 2016, the oil price in the global market decreased sharply from US\$145 per barrel in the mid of 2008 to about US $\$ 40$ per barrel at the end of 2008 . Then oil price increased at US\$ 77,11 per barrel in 2010 and a higher increased at US $\$ 91,39$ per barrel in 2011 as per report by Energy today, in year 2015. However, the oil price decreased slightly at US $\$ 88,95$ per barrel in 2012 and a further decreased at US\$ 49,93 per barrel in May 2016. Surprisingly, the oil price in Indonesia was not in line with the changes of oil price in the global market. In 2008, the oil price was lower than the crude oil price in the global market, which is US\$96,13 per barrel and then it decreased sharply to US\$61,58 per barrel in 2009 as per Indonesia Crude Price reports in year 2009. And then there was an increase at US\$79,4 per barrel in 2010 and a sharp increased to 112,73 per barrel. However, it declined significantly to US\$ 49,46 per barrel in 2016 as explained in report by MEMR in year 2016 .

\subsection{Development of Oil Industry in Indonesia}

Production sharing is rooted in the Napoleonic era French legal concept of the ownership of minerals, that mineral wealth should not be owned by individuals but by the state for the benefit of all citizens. Indeed, this philosophy is embodied in the 1945 Indonesian Constitution Article 33, which states that all the natural wealth on land and in waters is under the jurisdiction of the State and should be used for the benefit and welfare of the people (8). Unlike most countries, private individuals own most of the surface resources in the United States (9).

In the petroleum industry, Indonesia is the pioneer of the PSC, with the first contracts signed in the early and mid-1960s. Indonesia is the standard of comparison for all PSCs. PSC is a Business Agreement (a Petroleum Exploration and Production Agreement) between the Oil and Gas State Company or Authority Body and Contractor. SKK Migas is the Executive Agency for Upstream Oil and Gas Business Activities in Indonesia (established by GOI). All mineral oil and gas existing within the statutory mining territory of Indonesia are national riches, controlled by the state. The government holds "Exclusive Authority of Mine". The contractor has a Working Interest. The contractor has the financial ability, technical competence, and professional skills necessary to carry out the Petroleum Operations. The contractor is responsible to SKK Migas for the execution of operations in accordance with an agreed work. The term shall be 30 years from as from Effective Date. The contractors have permitted 6 years for exploration activity and have the option to request for 4 years' extension. If at the end of 6 years or the 4 years' extension thereto no petroleum commercial, the contract shall automatically terminate. In the event that contractor which received to develop its first field in contract area does not produce petroleum in commercial quantities within a maximum 5 years after the end of the exploration period, the contractor shall be obliged to relinquish the contract area to GOI. The basic features common to most PSCs are cost recovery, profit oil, and taxes. The financial issue of PSC is how costs are recovered and profits divided. Figure 1 shows how costs are recovered and profits divided in the Conventional Indonesian PSC.

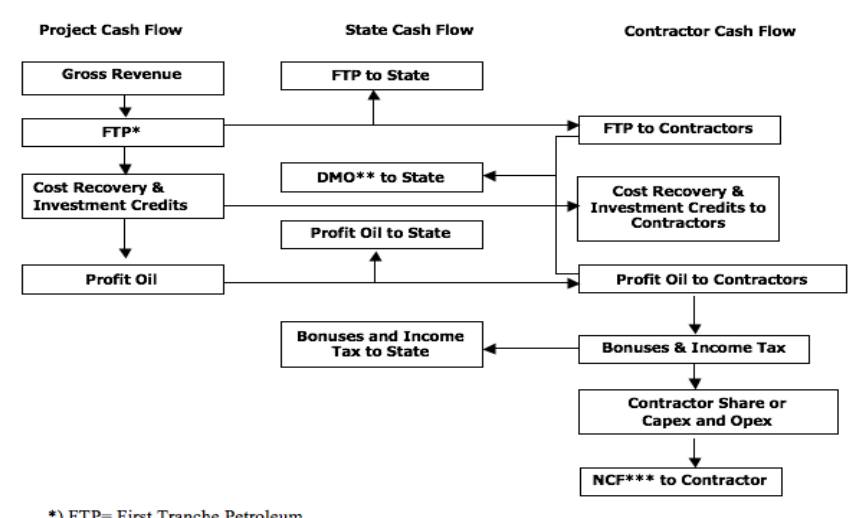

*) FTP= First Tranche Petroleur

$\left.{ }^{* *}\right) \mathrm{DMO}=$ Domestic Marke
$\left.{ }_{* * *}\right) \mathrm{NCF}=$ Net Cash Flow

Fig. 1: Structure of Conventional Indonesia PSC 


\subsection{Previous Research on Capital Budgeting Model}

According to Glinz \& Flores (10), the capital budgeting model is a tool to analyze the behavior of Oil Company's investment and its oil potential. This model is an application of Optimization Techniques and it has been employed successfully. According to Primadona; Tjendrasa, K. (2016), a financial evaluation is conducted to four type of PSCs model system using discounted cash flow analysis, and the parameter used for various oil production rates are Net Present Value (NPV) and Internal Rate of Return (IRR). Those parameters are effectively and widely used of an investment analysis. Before calculating the NPV and IRR, both GOI and PSC Contractor need to compute the cost of capital of the project. According to Sadvakassov \& Orazgaliyev (11), key factors in attracting Foreign Direct Investment (FDI) in the oil and gas industry of Kazakhstan emphasize that despite the presence of various motives in transnational corporation's investment decision, FDI to Kazakhstan mainly directed to the resource sector of the economy. According to Dunning (12), one of the investment motives is "searching for new resources" involving the search for resources not available in a firm's home country, such as mineral, hydrocarbons, agricultural raw material, cheap labor, etc. Based on the ideas mentioned above, the model was developed and will be used in this study is as shown in Figure 1.

\subsection{The Variables}

\section{a. Weighted Average Cost of Capital (WACC)}

In economic theory, the required rate of return should be equal to the company's cost of capital. This is the cost of debt capital plus the cost of equity capital, weighted by the relative amount of each in the company's capital structure. (3). Oil Company is a longterm business that using long term capital. There are four basic sources of long-term capital for firms: long-term debt, preferred stock, common stock, and retained earnings. In general, oil project uses two of these financing sources: long-term debt and common stock or equity.

\section{1) Cost of Long-term Debt (kd)}

Interest in long-term debt or bonds is tax deductible to the firm. Calculation of cost of long-term debt determined based on the after-tax basis. Based on the World Bank report in year 2015; currently the average of five years Indonesia's lending rate is $12.24 \%$, thus the interest rate (i) would be $12.24 \%+3 \%$ premium with the tax rate (T) is $25 \%$. Therefore, the cost of long-term debt $\left(\mathrm{k}_{\mathrm{d}}\right)$ is calculated as follows:

$\mathrm{Kd}=\mathrm{i}(1-\mathrm{T})=(12.24 \%+3 \%) x(1-25 \%)=11.4 \%$.

2) Cost of Equity $\left(\mathrm{k}_{\mathrm{e}}\right)$

The Capital Asset Pricing Model (CAPM) is one of the methods to find the cost of equity $\left(\mathrm{k}_{\mathrm{e}}\right)$. The CAPM indicates that the cost of common stock equity is the return required by the investor as compensation for the firm's non-diversifiable risk measured by beta (13). Based on CAPM, the variable can be calculated by using formula as follows; $r s=R F+\left[b x(r m-R m]\right.$, Where: $\mathrm{r}_{\mathrm{s}}=$ required return on common stock or cost of equity $\left(\mathrm{k}_{\mathrm{e}}\right) ; \mathrm{R}_{\mathrm{F}}=$ Risk free rate of return; $b=$ beta coefficient; $\mathrm{R}_{\mathrm{m}}=$ market return.

The value of risk-free rate of return can be measured by using interest rate in a trading market of long-term government bond. The yield value of Indonesian government bonds for tenor 20 years is $7.8437 \%$ as explained by Indonesia Bond Pricing Agency on April 25, 2016.

Beta coefficient values are calculated by using five years' historical data from several oil companies or based on an average of the unleveraged beta. This is done to neutralize the effect of firm's leverage that has different alternative leverage that effects to different equity cost. The impact of a unique capital structure on a firm's beta may be neutralized by un-levering its beta to the indus- try average or current capital structure. Unlevered beta is calculated by the following formula (14): $\beta_{\mathrm{L}}=\beta_{\mathrm{U}}\left(1+(1-T)\left(\frac{D}{E}\right)\right)$, Where: $\beta_{\mathrm{L}}=$ levered beta for equity in the firm; $\beta_{\mathrm{U}}=$ un-levered beta of the firm (i.e., the beta of the firm without debt); $\mathrm{T}=$ corporate tax rate; $\mathrm{D} / \mathrm{E}=\mathrm{Debt} / \mathrm{Equity}$ ratio. Based on the calculation of data from 351 firms, the average of the unleveraged beta of oil and gas companies is 0.95 (15). Thus, $0 \%$ debt and $100 \%$ equity financing has been assumed, and the tax rate is $25 \%$, thus levered beta is calculated as follows: $\beta_{\mathrm{L}}=0.95(1+(1-25 \%) 0 \%)=0.95$. Based on the country credit ratings assigned by Moody's and S\&P, Indonesia's market risk premium amounts to $9.05 \%$ (Damodaran, 2016). The cost of equity is calculated by using CAPM formula as follows: $k_{e}=7.8437 \%+[0.95 \times 9.05 \%]=16.44 \%$.

WACC reflects the expected average future cost of capital over the long run period; found by weighing the cost of each specific type of capital by its proportion of the firm's capital structure (16). Considering a very high risk at the upstream oil activities phase, the possible source of fund obtained only from equity. While in the development and production phases, the source of the fund may be obtained from the combination of debt and equity, and the percentage of debt is increasing in the production phase. Therefore, the proportion of equity in the exploration phase would be $100 \%$. Thus, the WACC of the oil business in Indonesia would be: WACC $=($ The proportion of long-term debt in capital structure $\mathrm{x}$ the cost of debt) + (the proportion of preferred stock $x$ the cost of preferred stock) + (The proportion of common stock equity $\mathrm{x}$ the cost of equity $)$. WACC $=(0 \% \times 11.43 \%)+(0 \% \times 0)+(100 \% \times$ $16.44 \%)=16.44 \%$.

\section{b. Net Present Value (NPV)}

NPV is calculated by multiply the cash inflow for each year by the present value of $\$ 1$ for that year at the appropriate rate of return. This process is called discounting the cash inflows. The rate at which the inflows are discounted is called the required rate of return, or the discount rate, or the hurdle rate. The difference between the present value of the cash inflows and the amount of investment is called the NPV. If the NPV is a nonnegative amount, the proposal is accepted (3). The formula is as follows: $N P V=\sum_{t=1}$ Discount Factor $*$ Net Cash Flow . Where: $\mathrm{t}=$ time when cash inflow or cash outflow is disbursed. It is assumed that all cash is disbursed at the end of the year.

\section{c. Internal Rate of Return}

The rate or discount factor that makes NPV equal zero is called the IRR, the formula is as follows:
IRR $=$ iNPV Positive $+\frac{\text { NPV Positive }}{\text { (NPVPositive-NPV Negative) }} *$
(iNPV Negative - iNPV Positive)

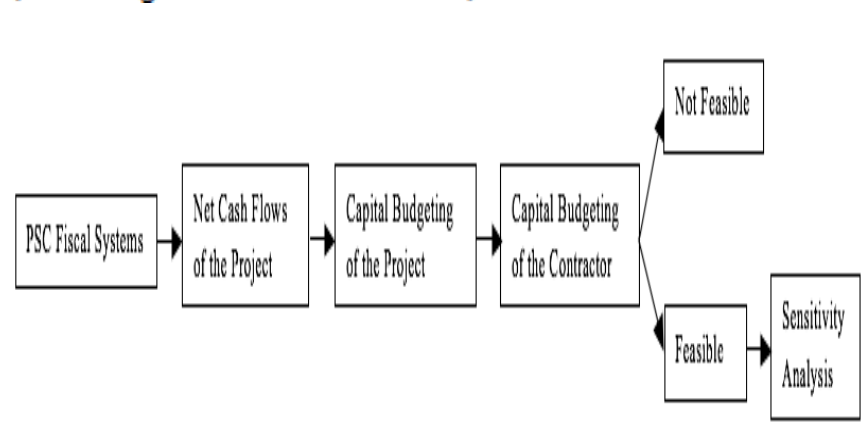

Fig. 2: Research Model.

\section{Methodology}

To accomplish this study, the steps are: (1) Study the terms and conditions of PSC Fiscal Systems (Figure 1) and apply for calculation of NCF Projects per oil field, respectively; (2) Calculate the 
capital budgeting of the project, and followed by the same calculation for the contractor; the results are: NPV, IRR, Simple Payback, (3) Make decision whether the project is feasible or not; (4) For the feasible projects, the sensitivity analysis is used to analyze how sensitive the NPV towards the changes of other variables involved ( PSC split, oil price, etc.) In this research, data were collected from 10 PSC oil fields in Indonesia, which have been operated in Indonesia during 1968 - 2014.

\section{Result and Discussion}

The assumptions used for terms and condition of PSC Fiscal Systems calculation are: 1) First Tranche Petroleum (FTP) $=20 \% ; 2$ ) Cost Recovery Limit; 3) Investment Credit $=17 \%$; 4) After Tax GOI $=85 \%$; 5) After Tax Contractor $=15 \%$; 6) Tax Rate $=48$ $\%$; 7) Before Tax GOI $=71.15 \%$; 8) Before Tax Contractor $=$ $28.85 \%$; 9) Domestic Market Obligation $(\mathrm{DMO})=25 \%$; 10) DMO Holiday $=5$ years; 11) $\mathrm{DMO}$ Fee $=10 \% ; 12) \mathrm{Up} \mathrm{Lift}=0.0$ $\%$; 13) Depreciation Type $=$ Double Declining Balance - Straight Line (DDB - SL); 14) Depreciation Period $=7$ years.

The assumptions used for Capital Budgeting calculation are: 1) WACC $=16.44 \%$; 2) Economic life $=30$ years; 3 ) Amount of cash inflow in each year is subject to the result of PSC calculation; 4) Amount of investment; 5) Terminal value $=\$ 0$.

Table 2 shows total Contractor Cash Flow calculation during the lifetime of the project ( 30 years). Out of 10 oil fields, 6 of them have negative NPV (Lematang, Sanga-sanga, SeramBula, Bawean, South Natuna.B, and North Sumatra Blok A), and the remaining have positive NPV, especially Rokan, with the highest $\mathrm{NPV}=\$ 303.83$, and followed by Kepala Burung, NPV $=\$ 63.16$; South East Sumatra, NPV $=\$ 40.26$; and CPP, NPV $=\$ 35.26$. The Simple Payback has ranged from $4-11$ years.

The production rate (bopd): 1) $\mathrm{CPP}=59,881.48 ; 2)$ Rokan $=$ $647,842.31$; 3) Sanga-sanga $=34,280.00 ; 4)$ Lematang $=237.50$; 5) Kepala Burung $=31,007.14 ; 6$ ) South Natuna $B=41,085.00 ; 7$ ) South East Sumatra $=97,485.71 ; 8$ ) Bawean $=1,563.64$; 9) North Sumatra Blok A $=5,643.48 ; 10)$ SeramBula $=958.33$. Oil fields which have negative NPV are the fields with low production rate, such as Lematang, Sanga-sanga, Seram Bula, Bawean, South Natuna B, and North Sumatra Blok A.Only 4 oil fields achieved the high IRR as compared with the hurdle rate of WACC, 16.44 $\%$, such as Rokan (57\%), Kepala Burung (43\%); South East Sumatra (39 5), and CPP (31\%). Therefore, the other 6 oil fields were not feasible.

Table 2: Total Contractor Cash Flow Calculation for 10 Oil Fields.

\begin{tabular}{|l|l|l|l|l|l|}
\hline $\begin{array}{l}\mathbf{N} \\
\mathbf{o .}\end{array}$ & Oil Fields & $\begin{array}{l}\mathbf{N C F} \\
(\mathbf{U S} \mathbf{\$ M})\end{array}$ & $\begin{array}{l}\mathbf{N P V} \\
(\mathbf{U S} \mathbf{\$ M})\end{array}$ & $\begin{array}{l}\text { IRR } \\
(\mathbf{\%})\end{array}$ & $\begin{array}{l}\text { Simple Pay- } \\
\text { back}(\mathbf{Y r s})\end{array}$ \\
\hline 1 & CPP & 527,35 & 35,26 & 31 & 6 \\
\hline 2 & Rokan & 4790,61 & 303,83 & 57 & 5 \\
\hline 3 & Sanga-sanga & 1003,46 & $-25,63$ & 13 & 10 \\
\hline 4 & Lematang & $-165,71$ & $-32,32$ & 0 & 7 \\
\hline 5 & $\begin{array}{l}\text { Kepala Bu- } \\
\text { rung }\end{array}$ & 628,59 & 63,16 & 43 & 4 \\
\hline 6 & $\begin{array}{l}\text { South Natuna } \\
\text { B }\end{array}$ & 63,34 & $-1,02$ & 13 & 11 \\
\hline 7 & $\begin{array}{l}\text { South East } \\
\text { Sumatra }\end{array}$ & 564,47 & 40,26 & 39 & 4 \\
\hline 8 & Bawean & $-29,25$ & $-9,49$ & -4 & 11 \\
\hline 9 & $\begin{array}{l}\text { North Sumatra } \\
\text { Blok A }\end{array}$ & 37,25 & $-0,34$ & 15 & 10 \\
\hline 1 & Seram Bula & $-4,23$ & $-11,39$ & 0 & 4 \\
0 & & & & \\
\hline
\end{tabular}

Table 3 shows Total Project Cash Flow calculation during the lifetime of the project (30 years). Out of 10 oil fields, 3 of them have negative NPV (Lematang, Seram Bula, Bawean), and the remaining have positive NPV. The Simple Payback has ranged from $2.6-20.3$ years. The IRR should be compared with WACC of $16.44 \%$. But the IRR of each project was very low, less than WACC. It is concluded that the projects did not feasible.
Table 3: Total Project Cash Flow Calculation for 10 Oil Fields.

\begin{tabular}{|c|c|c|c|c|c|}
\hline $\begin{array}{l}\mathbf{N} \\
\mathbf{o .}\end{array}$ & Oil Fields & $\begin{array}{l}\text { NCF } \\
\text { (US\$M) }\end{array}$ & $\begin{array}{l}\text { NPV } \\
\text { (US\$M) }\end{array}$ & $\begin{array}{l}\text { IRR } \\
(\%)\end{array}$ & $\begin{array}{l}\text { Simple Pay- } \\
\text { back (Yrs) }\end{array}$ \\
\hline 1 & CPP & 9955,6 & 826,7 & 0,9 & 14,8 \\
\hline 2 & Rokan & 82168,6 & 5100 & 0 & 18,3 \\
\hline 3 & Sanga-sanga & 20857,9 & 1007,3 & 0,7 & 8,7 \\
\hline 4 & Lematang & $-62,8$ & -25 & $-0,1$ & $-0,3$ \\
\hline 5 & $\begin{array}{l}\text { Kepala Bu- } \\
\text { rung }\end{array}$ & 4441 & 771 & 2 & 11,6 \\
\hline 6 & $\begin{array}{l}\text { South Natuna } \\
\text { B }\end{array}$ & 3497,1 & 145,8 & 1,4 & 4,5 \\
\hline 7 & $\begin{array}{l}\text { South East } \\
\text { Sumatra }\end{array}$ & 13286,7 & 999,7 & 1,3 & 8,1 \\
\hline 8 & Bawean & 49,9 & $-2,7$ & 0,1 & 0,4 \\
\hline 9 & $\begin{array}{l}\text { North Sumatra } \\
\text { Blok A }\end{array}$ & 670,2 & 35,9 & 0,6 & 20,3 \\
\hline $\begin{array}{l}1 \\
0\end{array}$ & Seram Bula & 47,7 & $-4,9$ & 0,1 & 2,6 \\
\hline
\end{tabular}

A sensitivity analysis is undertaken to investigate the robustness of the results and gain an understanding of how sensitive the project to the financial assumptions used in the cash flow model. The NPV is assessed against the oil price, and WACC, with PSC fiscal terms: split $=50: 50, \mathrm{FTP}=10 \%$ and tax rate $=48 \%$. The sensitivity analysis results are summarized in Figure 3 . The sensitivity analysis shows that at the production rate of 50,000-barrel oil per day (bopd), the project is more sensitive to the WACC rather than to the oil price. The WACC has expressed the risk of the oil project in Indonesia, which indicates that GOI should maintain the risk to lower down the WACC. Therefore, it is suggested the project achieve the stated oil target, or try to have cheaper financing as much as possible because it is difficult to predict oil price.

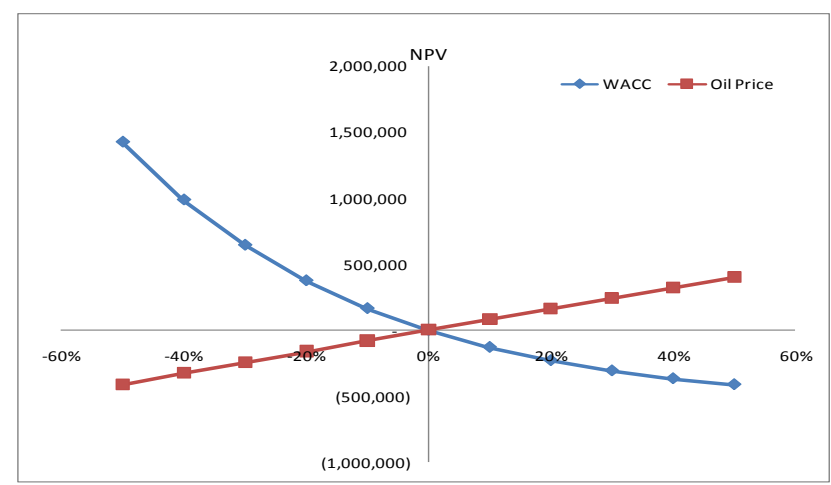

Fig. 3: Sensitivity Analysis.

\section{Limitation}

This study has expanded the literature about capital budgeting model and conventional oil PSC fiscal systems in the real working world. In near future, it is suggested to carry out research with many companies in the oil industry to get more generalizes result. Since the focus is on one industry, it is worth to explore it on a wider scale and find out if different company yields the same result. In addition, the study only focuses on financial aspects. Therefore, the research would be better if also includes the nonmonetary considerations, such as legal, operational, political, and administration. It is also suggested to carry out a similar research for other industries, such as mining, gas, geothermal, or estates industry.

\section{Conclusion and Recommendation}

The purpose of this study is to measure the feasibility of oil industry investment and to examine the attractive terms and conditions of PSC Fiscal Systems. The data were collected from the ten PSC Fiscal Systems which had been started the business since 1968 2014. The research found that from the point of views of oil inves- 
tors, the oil business is not attractive, unless the oil prices increase significantly, together with lowering cost of financing and operating. But it is very difficult to predict the oil price. The study found that the most important economic indicator, namely NPV, mostly negative, it means that the projects were not feasible. On the other hand, the oil reserves are getting drain with low rate oil production, and there is no new discovery unless there will be innovative of advanced technology. Oil business requires high capital, high technology, high risks, long-term commitment, but may be high returns. However, the GOI should think deeply how to invite the investors to participate in the business. The GOI may change the terms and conditions of the current PSC fiscal systems in order to attract the investors, but still favorable for the GOI. It is suggested that in the long run, the GOI should substitute the oil with other energy, such as renewable energy: geothermal, wind, biomass, hydro, solar PV, and micro-hydro. The country should not always depend on oil forever, it should transform from non-renewable energy to renewable. The study is also beneficial for the academicians and students to understand capital budgeting model and PSC Fiscal Systems.

\section{References}

[1] Tharakan P. Summary of Indonesia's Energy Sector Assessment. 2015.

[2] Group WB. Doing business 2013: Smarter regulations for small and medium-size enterprises: World Bank Publications; 2012.

[3] Anthony RN, Hawkins DF, Merchant KA. Accounting: text and cases: McGraw-Hill; 2011.

[4] Frederer J. Oil Price Volatility and Macroeconomy: A solution to the asymmetry Puzzle. Journal of Macroeconomics. 1996;18(1):126.

[5] Belke A, Orth W, Setzer R. Liquidity and the dynamic pattern of asset price adjustment: A global view. Journal of Banking \& Finance. 2010;34(8):1933-45.

[6] Anzuini A, Lombardi MJ, Pagano P. The impact of monetary policy shocks on commodity prices. 2012.

[7] Regnier E. Oil and energy price volatility. Energy Economics. 2007;29(3):405-27.

[8] Lubiantara B. Ekonomi Migas: tinjauan aspek komersial kontrak migas: Gramedia Widiasarana Indonesia; 2012.

[9] Williamson HF, Daum AR, Klose GC. The American Petroleum Industry: The Age of Illumination, 1859-1899; Vol. 1: Greenwood Publishing Group; 1963.

[10] Glinz I, Flores I. Capital Budgeting Model for Pemex Exploración y Producción. Сетевое издание «Нефтегазовое дело». 2006(2).

[11] Sadvakassov D, Orazgaliyev S. Key factors in attracting foreign direct investments in the oil and gas industry of Kazakhstan. Актуальні проблеми економіки. 2015(4):147-54.

[12] Dunning JH. The eclectic paradigm as an envelope for economic and business theories of MNE activity. International business review. 2000;9(2):163-90.

[13] Gitman LJ, Chad J. Zutter.(2012). Principle of Managerial Finance. 2012.

[14] Damodaran A. Investment valuation, 2. Aufl, New York. 2002;817.

[15] Damodaran A. Total Betas by Sector (for computing private company costs of equity)-US. Damodaran on line. 2016.

[16] Zutter CJ, Gitman LJ. Principles of Managerial Finance, Brief: Pearson Higher Ed; 2011. 